\title{
JOMSTI
}

\section{Trompong, Trombone, Trumpet, and Jegogan in Trom-Trom-Trum Composition}

\author{
Agus Cahyadi ${ }^{1}$, Ni Wayan Ardini $^{2}$, Desak Made Suarti Laksmi ${ }^{3}$, \\ Ketut Sumerjana ${ }^{4}$ \\ ${ }^{1}$ Trojan Band, ${ }^{234}$ Music Department, Institut Seni Indonesia Denpasar \\ email: ${ }^{1}$ guz.cilix@gmail.com, ${ }^{2}$ niwayanardini17@gmail.com, \\ 32desaksuartilaksmi@isi-dps.ac.id, ${ }^{4}$ sumeriana@gmail.com
}

\begin{abstract}
ABSTRAK
Trom-Trom-Trum diciptakan oleh seniman Bali I Nyoman Windha pada tahun 2003. Judul ini merupakan ungkapan dari penggunaan kombinasi alat musik trompong, trombone, dan trompet yang digunakan dalam komposisi musik ini. Dua di antaranya adalah instrumen Barat, yaitu trombone dan trompet, dan instrumen lainnya adalah gamelan Bali, yaitu trompong dan satu pasang jegogan yang fungsinya dalam komposisi ini sebagai aksen. Metode penelitian yang digunakan adalah metode kualitatif, dengan teknik pengumpulan data melalui observasi, wawancara, studi dokumen, dan diskografi. Hasil penelitian menunjukkan, dalam Trom-Trom-Trum, dari aspek musikalnya, terdapat kaidah-kaidah seperti ketentuan jumlah birama, tanda sukat, progress chord, dan pola ritme yang harus dibawakan sesuai dengan yang ditentukan. Komposisi ini menggunakan nada dasar $\mathrm{C}$, dengan tempo allegro (100MM) dan memakai sukat 9/8. Komposisi ini berbentuk tiga bagian, yaitu AABCAAB, yang diawali dengan introduksi.
\end{abstract}

Kata kunci: komposisi, Trom-Trom-Trum, trompong, trombone, trompet, jegogan.

\begin{abstract}
Trom-Trom-Trum was created by Balinese artist named I Nyoman Windha in 2003. It is an expression of combination of musical instruments used in this composition: trompong, trombone, and trumpet. The two of them (trombone and trumpet) are western instruments, and the rest is a Balinese gamelan instrument namely trompong added with one pair of jegogan which function in this composition as an accent. The research method is qualitative, using some techniques of data collection, they are observation, interviews, document studies, and discography. The result of the study shows, in Trom-Trom-Trum, from the musical aspects, there are rules such as the provisions of the number of bars, signs of sukat, progress chords, and the rhythm pattern that must be delivered according to what is specified. This composition uses basic C notes, with allegro tempo (100MM) and uses 9/8 sukat. The composition is in the form of three parts, namely AABCAAB, which begins with introduction.
\end{abstract}

Keywords: composition, Trom-Trom-Trum, trompong, trombone, trumpet, jegogan. 


\section{INTRODUCTION}

Bali is one of the provinces and a socio-cultural unity in Indonesia where the local people are almost never separated from the musical entities in their daily behavior. In Bali, most music is used for religious rituals/ceremonies. It was in that environmental condition an artist named I Nyoman Windha was born in Banjar Kutri, Singapadu Village, Gianyar, on July 4, 1956.

Like other Balinese, since childhood Windha has been familiar with the sounds of gamelan and energetic songs which are full of motion and diversity of sounds. In 2005 he completed her master of music at Mills College California. One of the contemporary music compositions he created in 2003 that's when he attended his master program was Trom-Trom-Trum which means "trompong, trombone, and trumpet”. He was inspired when he collaborated with musicians from Gamelan Sekar Jaya California, a group of Western musicians who are very good at playing Balinese instruments or gamelan. In Bali it will be a little more difficult to find trombone and trumpet players who understand Balinese gamelan and can play the composition.

Dudley Brooks and James Harding are Western musicians and members of Gamelan Sekar Jaya who can play trumpet and trombone very well. Brooks fills the trumpet part and Harding fills the trombone one in this composition. Annie Gosfield, Windha's lecturer while studying Master of Music at Mills College California, offered to play a pair of jegogans. Windha himself plays trompong.

In the 1970s, new types of music emerged in several places in Indonesia such as contemporary music. Contemporary music is even more like 20th century music. Contemporary music is composed for all types of instrument combinations, not only traditional gamelan, although sometimes it uses gamelan. Sometimes theater, dance or narrative performances are accompanied by contemporary music. Most contemporary composers are teachers at the Indonesian Music Academy, and their compositions are played at schools or art festivals sponsored by the government. Contemporary music has never been used in villages or for rituals.

The authors are interested in Trom-Trom-Trum because this composition is so beautiful created using only melodic instruments without the instruments of harmony and rhythm. The authors want to observe the shape of musical structures 
and functions to be analyzed, so that with the analysis of musical shapes and structures and functions, this composition can be understood in more detail.

Everyday life involves a lot of music, not only in Bali. The most basic definition of music itself is regular sound. In regular sounds there are elements of music and to know these elements there is an analysis of song form and structure as in the writings of Ariesta, et al (2018, $\underline{\text { http://jurnal.isi- }}$ dps.ac.id/index.php/jomsti/article/view/504) and Mahardika (2018, http://jurnal.isidps.ac.id/index.php/jomsti/article/view/26).

\section{RESEARCH METHODS}

For many people, music is a fun entertainment. A lot of people enjoy music but only a few who try to understand it. According to Andjani (2014: 1), music is a universal art that can be accepted by humans with its various differences as well as an inseparable part of human life. Music is the art of composing tones or sounds, so that it can cause compositions that have a unity and a combination of musical elements such as melody, rhythm, harmony, dynamics, and tempo.

Djohan (2005: 260) classifies music as the science or art of setting the tone to produce compositions that have unity, continuity and agreed upon sound. Kamien (1998: 2) says music is part of the world of sound, an art that is based on organizing sound in its time.

Music works are synonymous with composition of tones and harmonization to form a complete musical work. Prier SJ (1989: 87) said that music composition is a composition in the form of song form, ensemble form, sonata form, opera form, oratario form, and symphony form. Prier SJ (1996) describes several theories about the analysis of musical forms and their analysis techniques.

Banoe (2003) explains the elements of musical composition and musical forms based on the order of songs determined according to the parts of the sentence. According to Prier SJ (1996: 2), the form of a song is an idea that appears in the processing/arrangement of all musical elements in the composition of melody, rhythm, harmony, and dynamics.

Analysis is the process of reducing the complexity of a complex phenomenon to the discussion of the most elementary parts or the simplest parts (Chaplin, 2005: 25). Analysis is the process of outlining the parts of the whole up to the simplest 
discussion, to find the elements that exist in a musical work as an object of research. These elements start from melody, rhythm, harmony, form and structure of songs, signs of expression.

Types of data sources that will be used in this study are qualitative data. To get data and information, the authors use several techniques to collect data, namely, observation, interviews, documentation, and discography. Primary data sources obtained from direct observations and interviews with informants, such as composers, personnel, connoisseurs, and also through research on recordings and scores of Trom-Trom-Trum. Secondary data were obtained from literature studies, namely book sources, internet journals and documents that have relevance to this research.

\section{RESULTS AND DISCUSSION}

\section{Music Composition Trom-Trom-Trum}

Literally the term composition means to compile together. The term is especially suitable to mention the beginning of polyphony music, in which the sound types (sounds) are actually arranged together (Bandem, 2013: 148). Windha in the cultivation of music Trom-Trom-Trum uses the concept of three main instruments that begin with the letter "t". The concept of three (tri) is a number that is often used in the lives of Balinese people, especially those who are Hindu. Many concepts of Hindu-Balinese life use the concept of three or tri, from which the three concepts Windha chose three main instruments beginning with the letter "t".

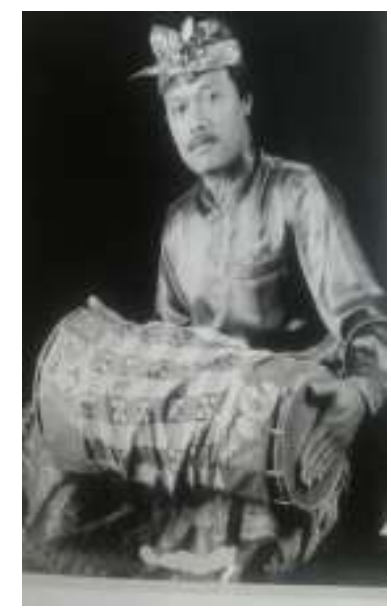

Figure 1

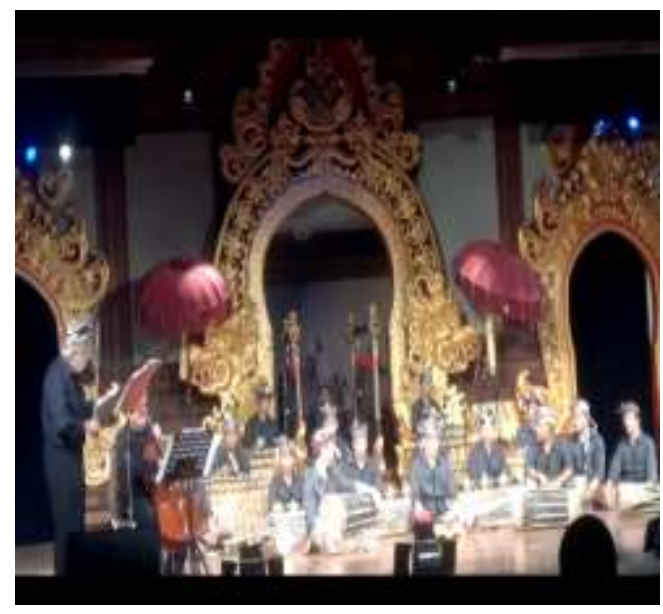

Figure 1.

I Nyoman Windha and the performance of 
Trom-Trom-Trum composition in the 2012 Bali Arts Festival (Source: I Nyoman Windha, 2012).

Trom-Trom-Trum is Windha's first composition to collaborate using brass instruments namely Trombone and Trumpet, and is also the first composition to collaborate without using Gong Kebyar. This composition was inspired by Lou Harrison, a composer from Oregon, United States who was born on May 14, 1917. Harrison was Windha's lecturer while undertaking master studies at Mills College, United States. At that time Harrison was a lecturer in World Music, his works were synonymous with collaborative music using Javanese gamelan. Mills College has a Javanese Gamelan classroom which is Harrison's teaching room. Harrison's works greatly inspired Windha in creating collaborative and contemporary compositions, one of which was Trom-Trom-Trum.

\section{“Trompong”, Trombone, Trumpet, dan “Jegogan”}

Trombone is a brass instrument whose material comes from metal. The word "trombone" means "big trumpet". This word comes from Italian, "troba" (meaning trumpet) which is added with a "-one" affix. The shape of the bottom of this instrument has a "stem" that can be shifted, functioning as a tone modifier. Trombone is included in the category of aerophone instruments, which means musical instruments that use sound sources in the form of air.

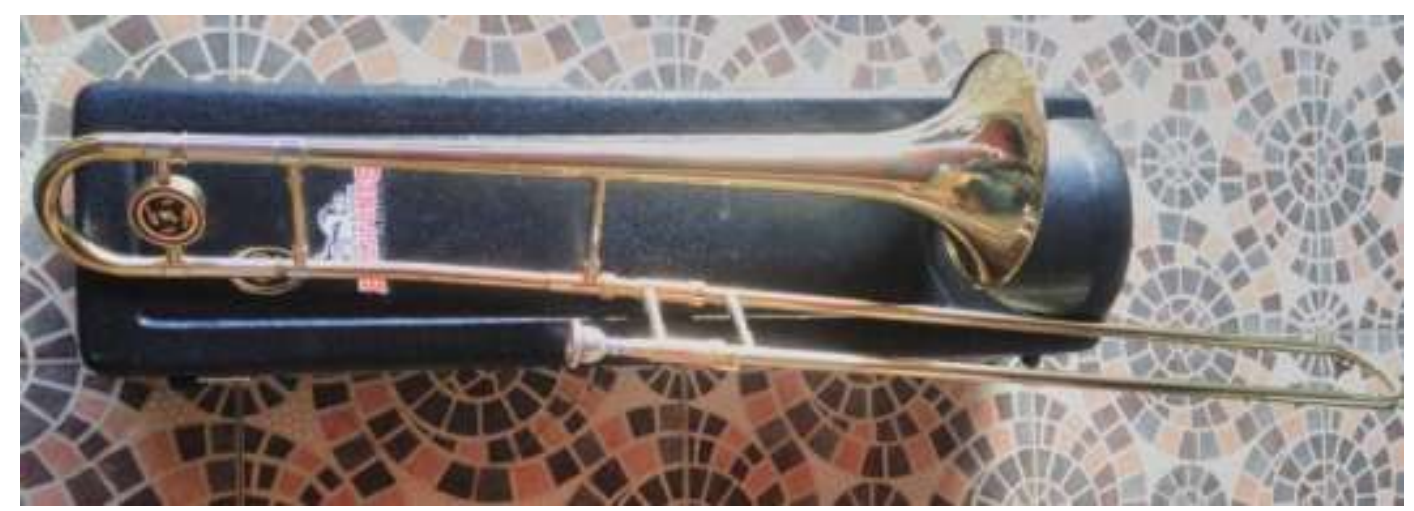

Figure 2.

Trombone

(Source: Agus Cahyadi, 2018).

Trumpets are the instruments used primarily in classical and jazz music. The most common type of trumpet is the $\mathrm{Bb}$ trumpet, which means that if a player plays 
$\mathrm{C}$, it will sound like $\mathrm{Bb}$ in a concert pic. Trumpet plays by blowing into a pinch and making a "buzz" sound. The Trumpet has only three buttons, and the trumpet player has to adjust the embouchure to get a different tone. Trumpets fall into the category of aerophone instruments which means musical instruments that use air-sound sources.

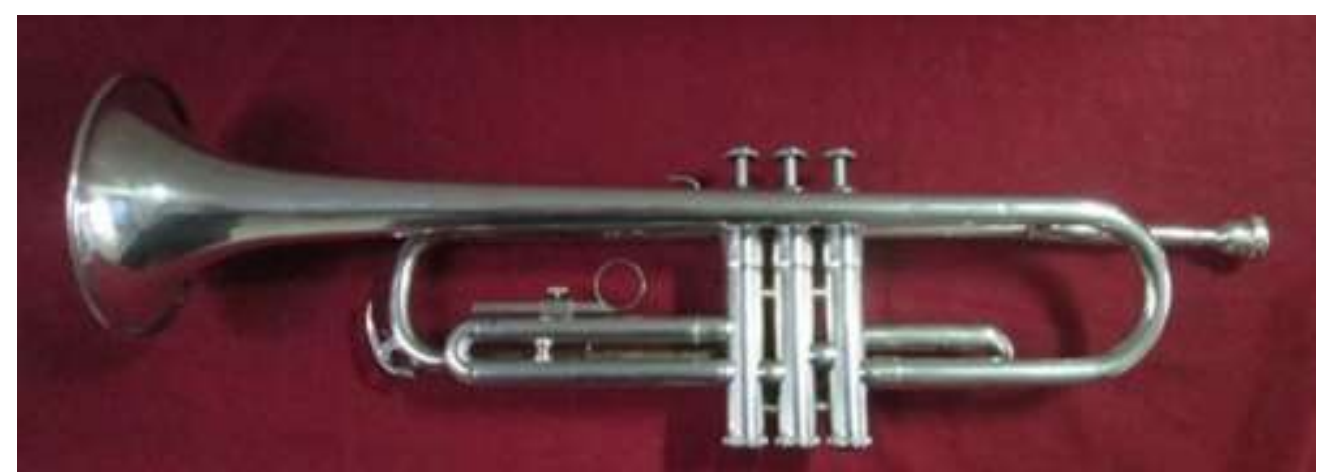

Figure 3

Trumpet

(Source: Agus Cahyadi, 2018).

Trompong is one part of the Balinese gamelan called gong kebyar. Trompong has 10 small, hollow horizontal gongs, the frequency range includes two octaves and has a pelog tone. Trompong is played by one player by using two bats which are commonly called pelvis. Trompong is included in the category of ideophone instruments, which means musical instruments whose source of sound comes from the instrument itself.

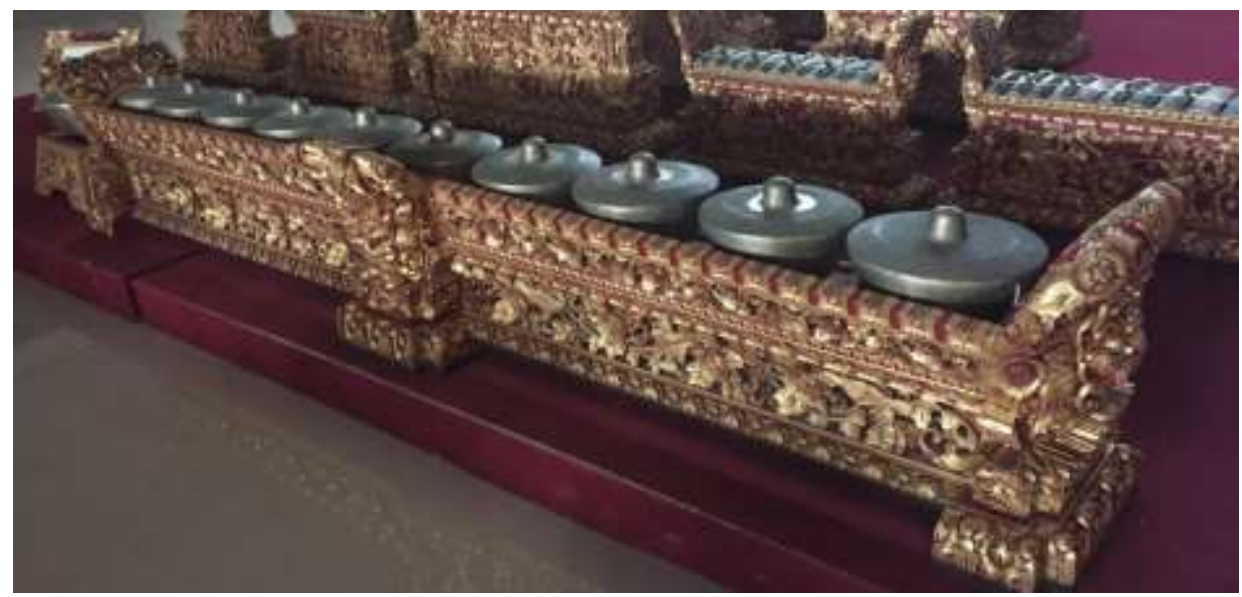

Figure 4

"Trompong"

(Source: Agus Cahyadi, 2018). 
Jegogan is the lowest octave instrument in gamelan gong kebyar. Consists of five pelog pitched blades made of perunguu and uses long bamboo as its resonance. Played using a paddle or commonly called the pelvis and in a sitting position using a chair. Jegogan is included in the category of ideophone instruments, which means musical instruments whose source of sound comes from the instrument itself.

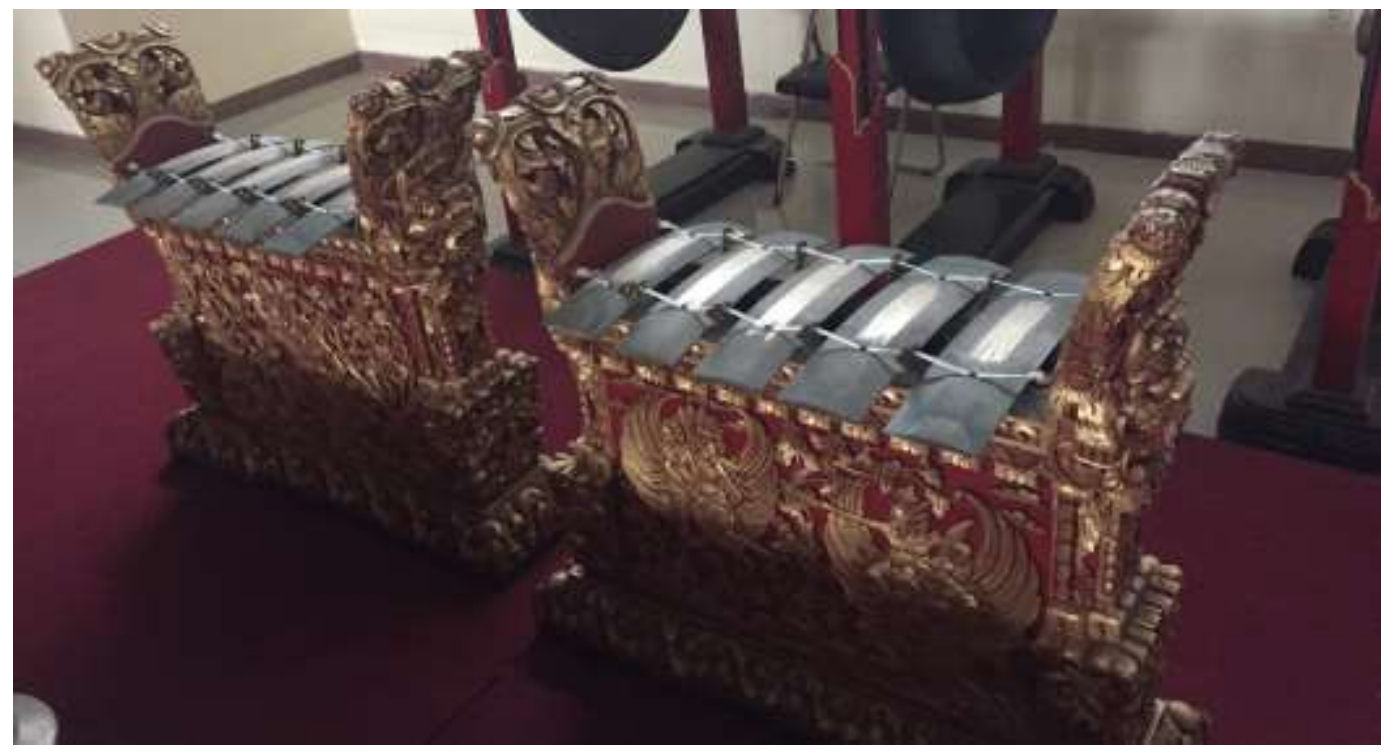

Figure 5 Jegogan

(Source: Agus Cahyadi, 2018).

\section{Form Analysis, Structure, and Composition Instrumentation}

There are several forms and structures contained in musical works, as said by Prier SJ (1996: 5), the first is a one-part song form: with just one sentence, two-part song form: with two different sentences, three-part song form : with three different sentences. In the same vein, Banoe (2003: 151) classifies that musical form based on the order of songs determined according to the parts of the sentence. As in language literature, music also has syllables, phrases, sentences, clauses and so on that can be analyzed in various forms: $A B, A B A, A B C, A B A C$, formulated in various terms: binary-form, ternary-form, rondo -form, variation-form, strophic-form, freeform, sonata-form, fugue-form, and so on. The form of the Trom-Trom-Trum sheet can be seen in Figure 6. 
Journal of Music Science, Technology, and Industry Vol. 2 No. 2 (2019): 145-168 E-ISSN 2622-8211

2
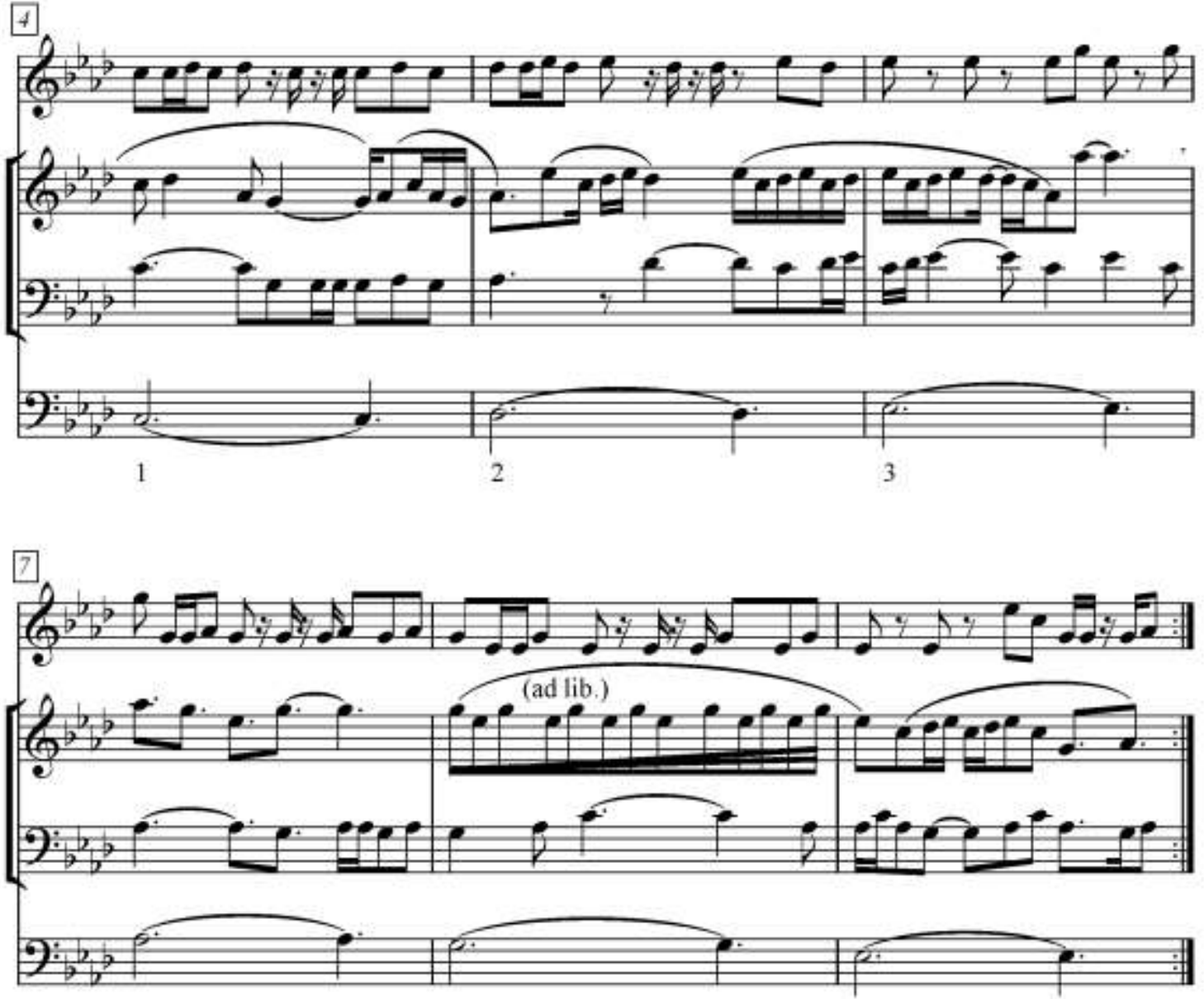

5

4

3

(B)

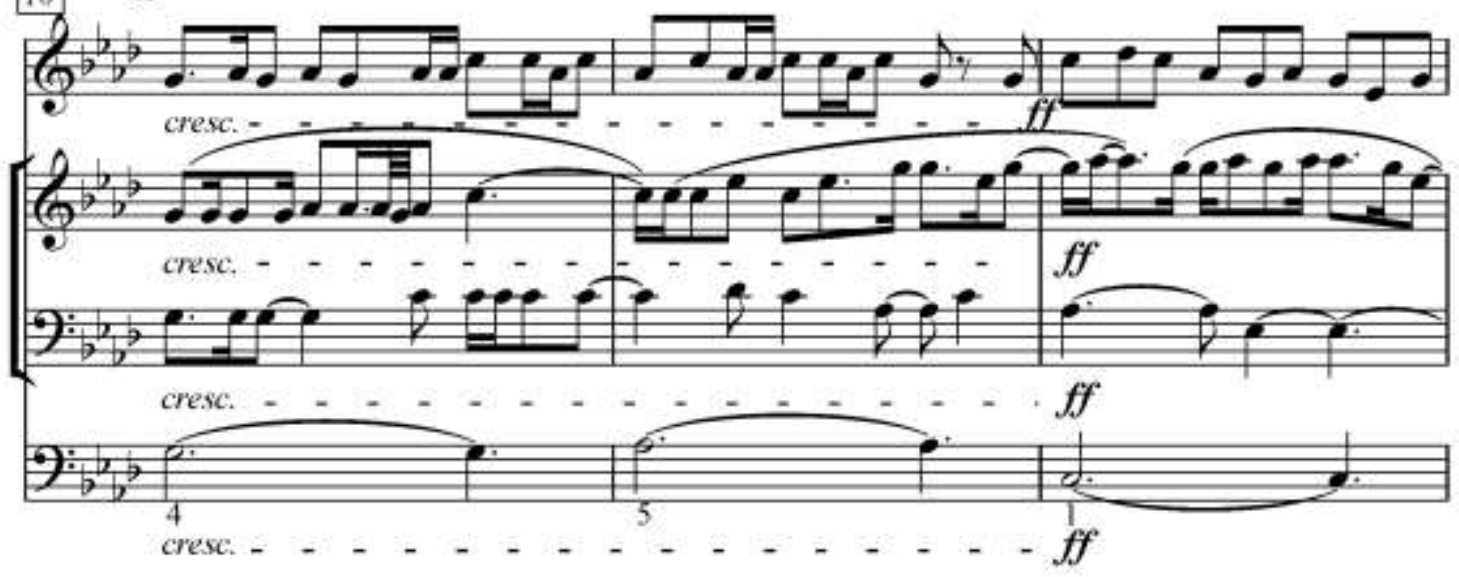



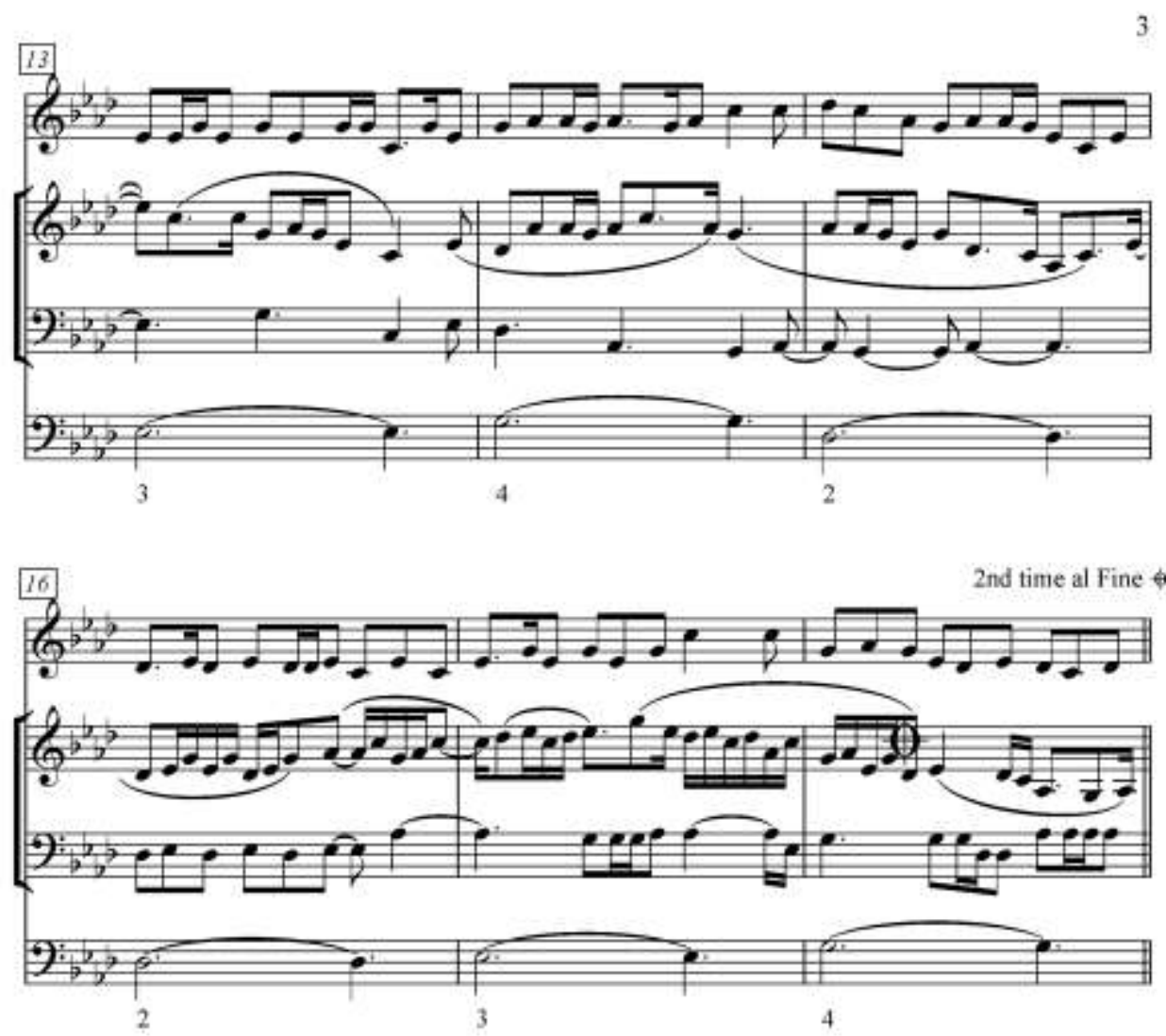

(C)

Dal Segno \& al Fine
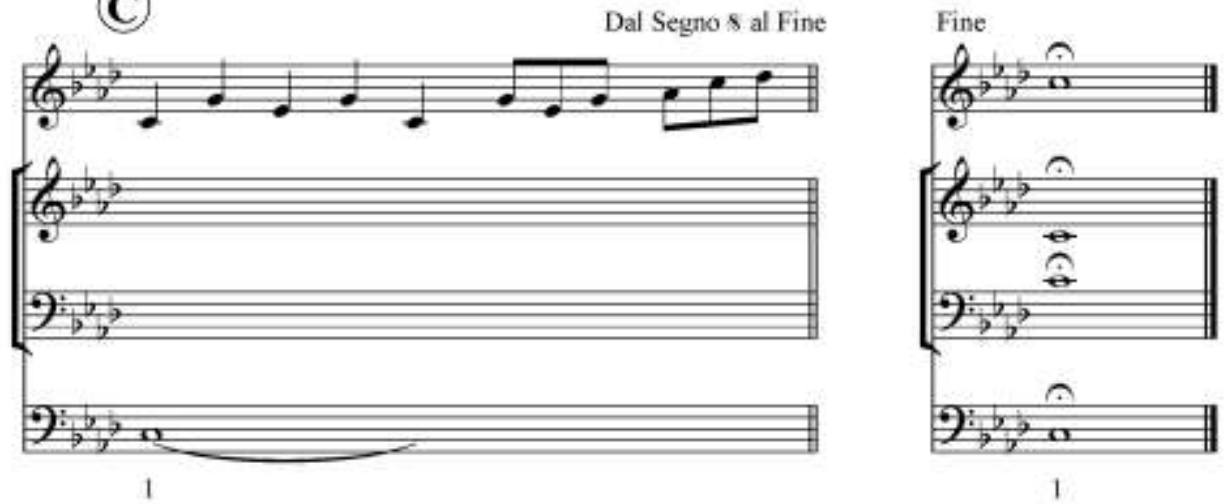

Figure 6

Trom-Trom-Trum score

(Source: I Nyoman Windha, 2003).

Structure in a musical work is composed of basic elements that have been arranged so that the musical work is formed. The basic elements consist of melody, rhythm, harmony, dynamics, tempo, and the shape or structure of the song (Jamalus, 1988: 7). Based on this opinion, the discussion about the analysis of the form and structure of the musical composition Trom-Trom-Trum is classified in the form of a three-part song namely $A A B C A A B$ where $C$ in this composition is only a 
transition bridge that is played solo with trompong. In general, the composition structure of gamelan gong kebyar has an ABC shape where in part $A$ it is often called kawitan, part $B$ is called a comedian, and part $C$ is called a painter.

\section{Introduction}

Introduction is an opening, vocal accompaniment music usually begins with intro (introduction) before entering the vocal sound (Banoe, 2003: 197). The information about the introduction can be seen in Figure 7.
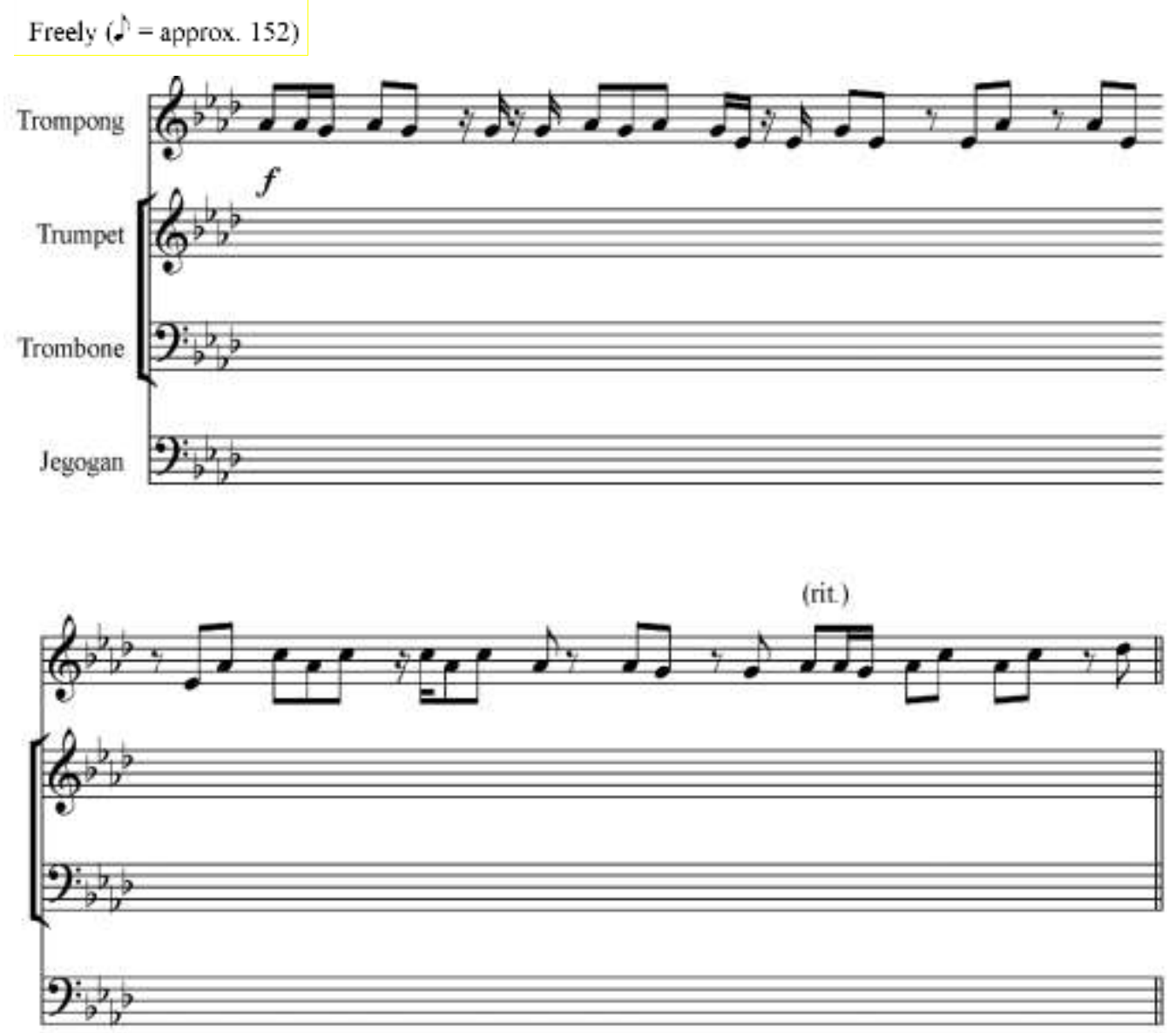

Figure 7

Introduction

(Source: I Nyoman Windha, 2003).

In Figure 7, the introduction or kawitan section is played solo with trompong and played freely without sukat. The melody lasts for 43 beats, with the jegogan tone at the end, where the trumpet enters with the jegogan, and with the same tone. In this section the trompong player has the freedom to improvise with playing techniques and with tempo. It starts with a fast tempo and enters the 18th beat. The 
tempo starts to slow down and reach normal when the other instruments start simultaneously. The tempo slows down and finally reaches the normal tempo.

At the introduction, there is a beginning mark of 4 moles which means that the basic tone in this introduction is played with the basic tone $A s=$ do, in which this basic tone adjusts the basic tone of the trompong, ding = do. The dynamics used in this section are forte $(f)$ which is a hard dynamic.

\section{Part A}

Part $A$ is a period consisting of two phrases, namely the question phrase (antecedent) and the answer phrase (consequent). According to Prier SJ (1996: 2), a period is a number of time bars (usually 8 or 16 bars) which constitute a unity. For sentences/periods, uppercase letters are generally used ( $A, B, C$, etc.). If a sentence/period is repeated with changes, the capital letters are accompanied by an accent (') such as A B A'. In this section using the 9/8 sukat which means that in one bar consists of 9 beats, each beat is worth 1/8 where the progress chord used in this section can be seen in Figure 8.

As $=$ do

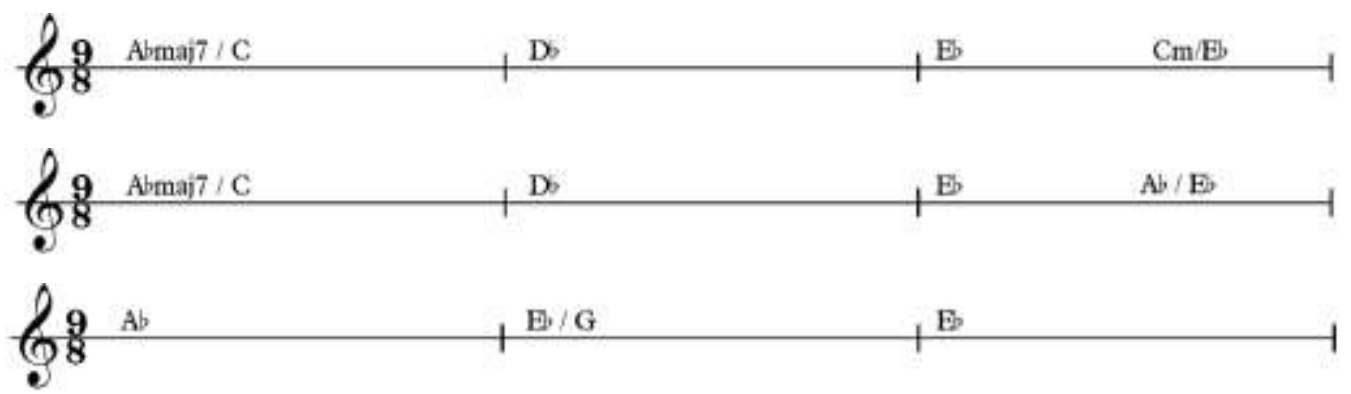

Figure 8

Progress chord part A

(Source: Agus Cahyadi, 2018).

Figure 8 shows that, in one bar there is one chord with a count of three taps, except for bars 3 and 6 there are two chords. The tempo used in this section is allegro (100MM) which is a fast and happy tempo, and there is a starting mark of four moles which means that this composition is played with the basic tone As = do. The dynamics used in this section are forte $(f)$.

Dynamics is the softness of softness in playing music, expressed by various terms such as: forte (f) which is a loud dynamic (Banoe, 2003: 116-275). The 
description of the period part A, dynamics, question phrases (antecedents) and answer phrases (consequent) can be seen in Figure 9.

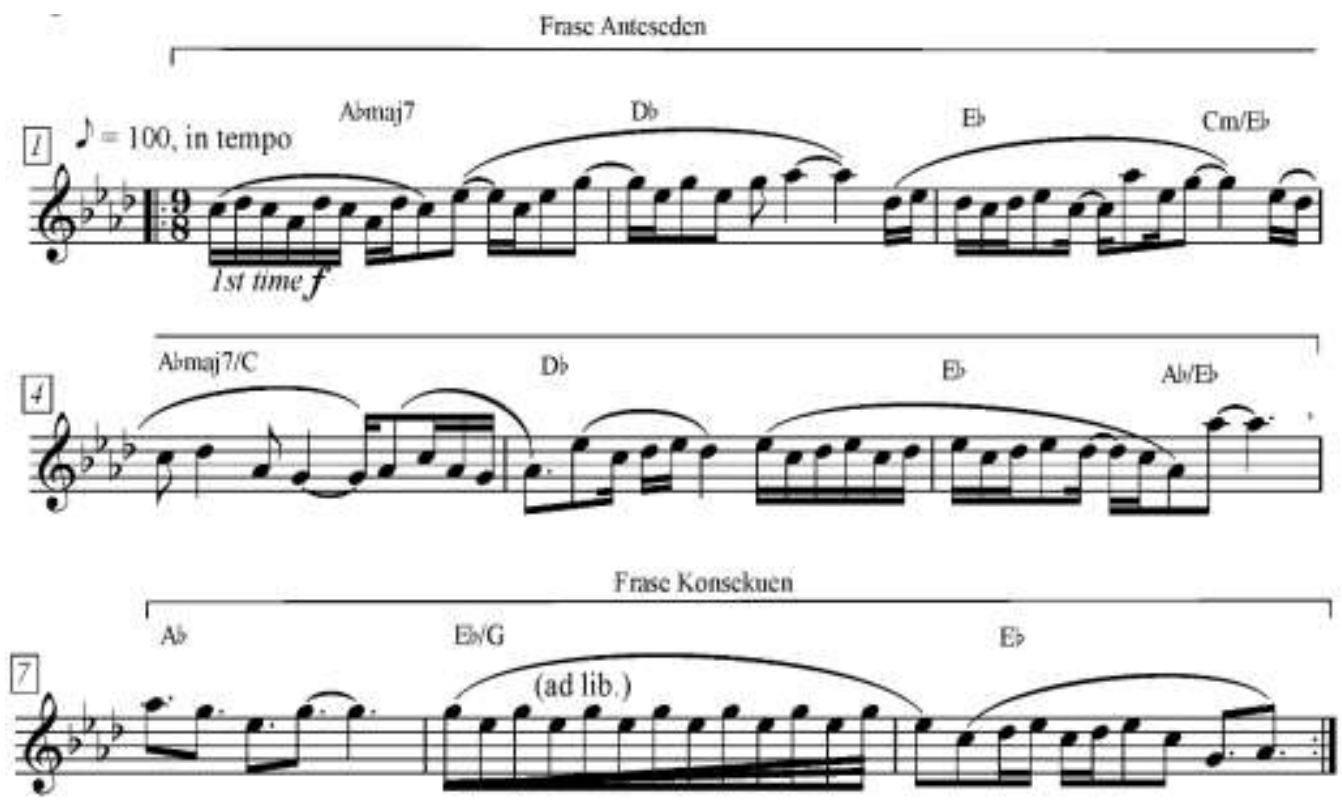

Figure 9

Period part A

(Source: Agus Cahyadi, 2018).

From the description of Figure 9, it can be concluded that, this section consists of 9 bars, which start from time 1 at the beginning of the beat to time 9 at the end of the beat. This section consists of two phrases, namely antecedents and consequent phrases, which in the antecedent phrase are semi-phrases, and there are no semi-phrases in consequent phrases.

The antecedent phrase in this section starts from the time 1 bar starting at the beginning until the last 6. According to Prier SJ (1996: 2), the initial antecedens phrase or number of bars (usually 1 - 4 or $1-8$ ) is called a question sentence or front sentence, because it usually stops in a floating tone. It can be said with "commas" in which generally here there is a dominant chord. The impression here is not finished, it is expected that the music will continue. The description of the antecedent phrase can be seen in Figure 10. 


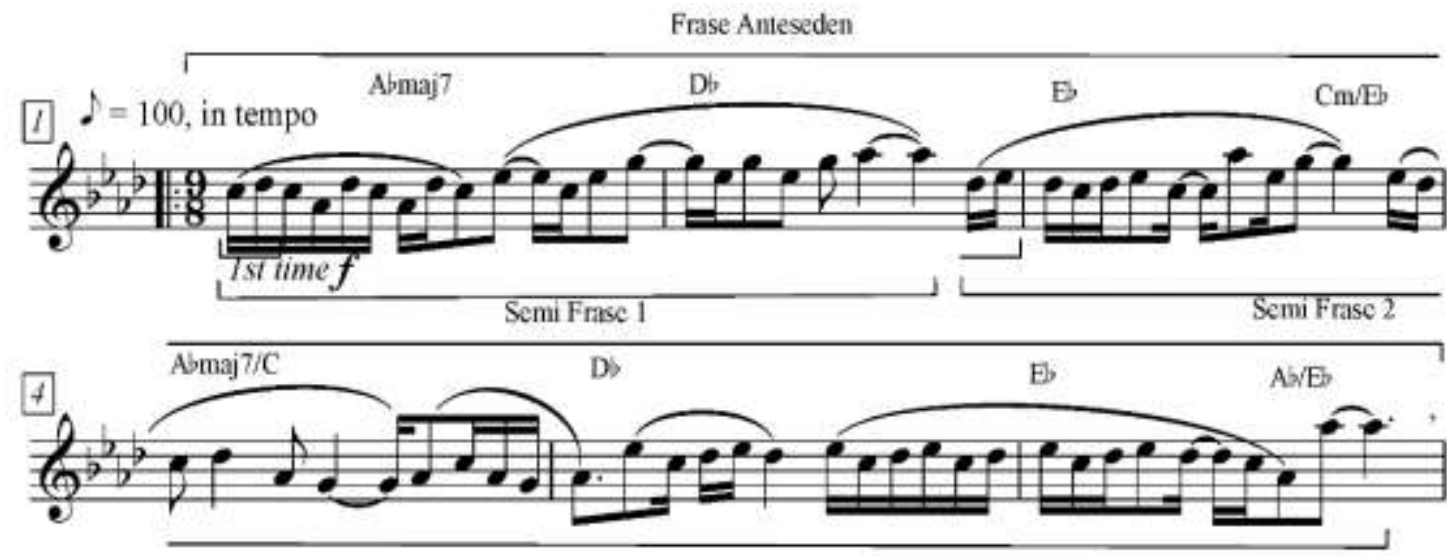

Figure 10

Antecedent phrases and semi-phrases part $A$

(Source: Agus Cahyadi, 2018).

The description of Figure 10 shows that, this phrase consists of six bars, and there are two semi-phrases. The semi-phrases in the figure above function that there are half sentences in the processing of the breath both for vocals and played with instruments. In part A there are no similar motives.

Normally, a song motive fills two bars of space. Therefore, even a clause (for example with 4 bars) generally consists of 2 motives A 2 bars, in accordance with the law of symmetry. Symmetry means that a sentence with, for example, eight brama spaces is divided into two parts of equal length. The first four bars are called questions or front sentences, the following four bars are called answers or back sentences. The question or answer sentence with, for example, four bar rooms is divided into two parts of equal length. The first two bars are called the first motive; the following two bars are called the second motive (Prier SJ, 1996: 3).

The consequent phrases in this section start from time 7 at the beginning of the beat to time 9 at the end of the beat. In contrast to the antecedent phrase in this section, the consequent phrases in this section do not have a semi-phrase because of the short duration and composition which has a form which deviates from the rules. According to Prier SJ (1996: 19), every exception to the general rules must be supported by a reasonable reason, which adds to the beauty. Windha said that Trom-Trom-Trum is an abstract composition that does not use the theory of the science of composition. This composition tends to be free without the rules of Western music science. The consequent phrase description can be seen in Figure 11. 


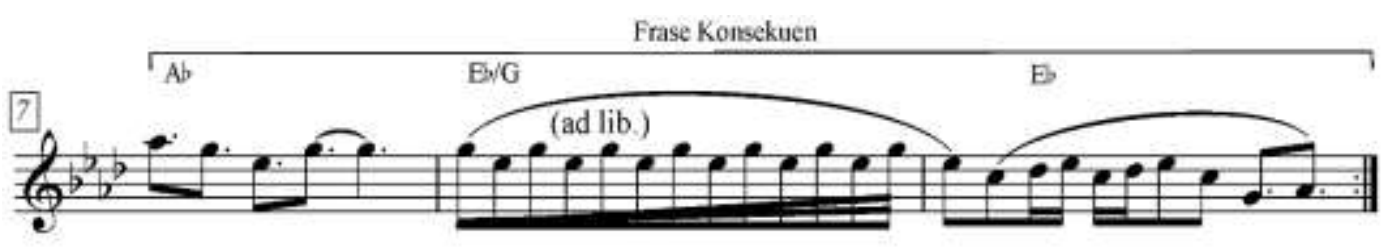

Figure 11

Consequent phrases

(Source: Agus Cahyadi, 2018).

The description of figure 11 shows that, in this phrase consists of three bars and there is no semi-phrase and also no motive because this composition is one that deviates from the rules. Each instrument in this composition plays a melodic pattern that is not the same. After an explanation of the trumpet game, the pattern of the trombone game can be seen in Figure 12.
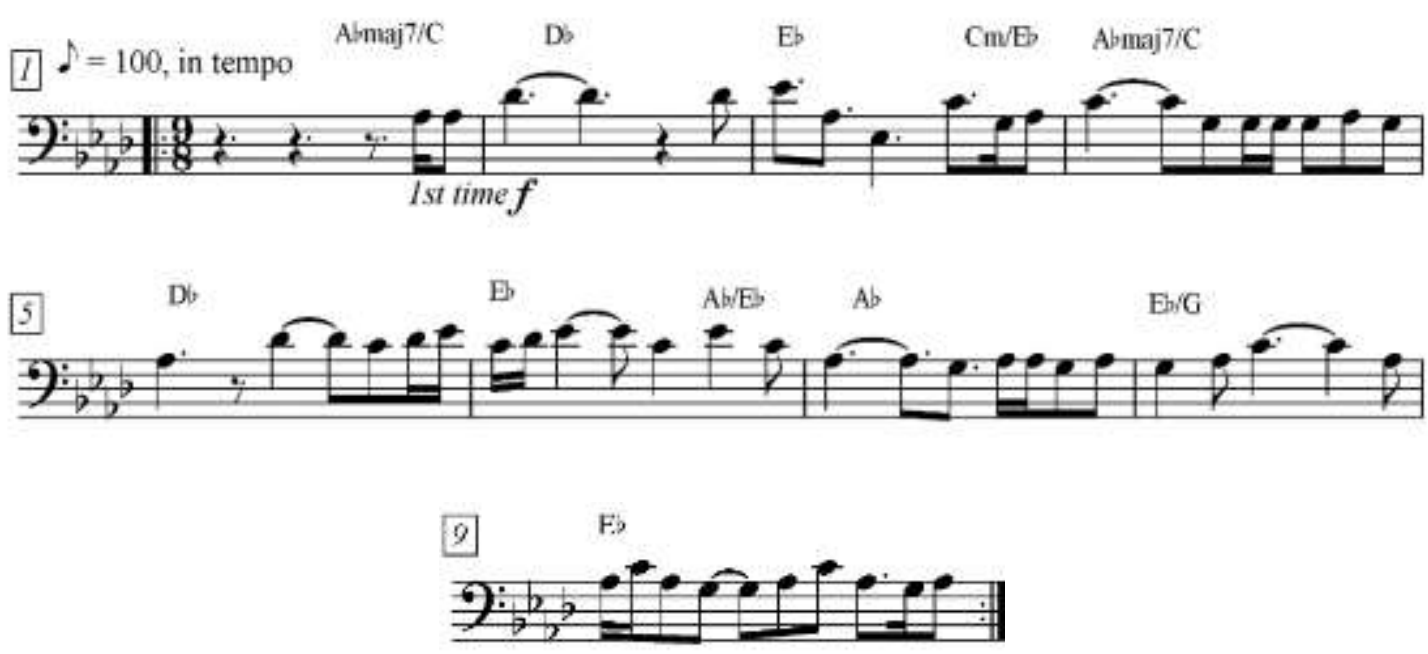

Figure 12.

Game pattern of trombone part A

(Source: Agus Cahyadi, 2018).

Figure 12 shows that the trombone game in this section acts as a companion and as a chord progressive. Trombone in this section plays a different pattern than the trumpet and plays the melody on its own without having to match the main melody of the trumpet. After the explanation of the trombone game, it is then followed by the trumpet playing pattern which can be seen in Figure 13. 


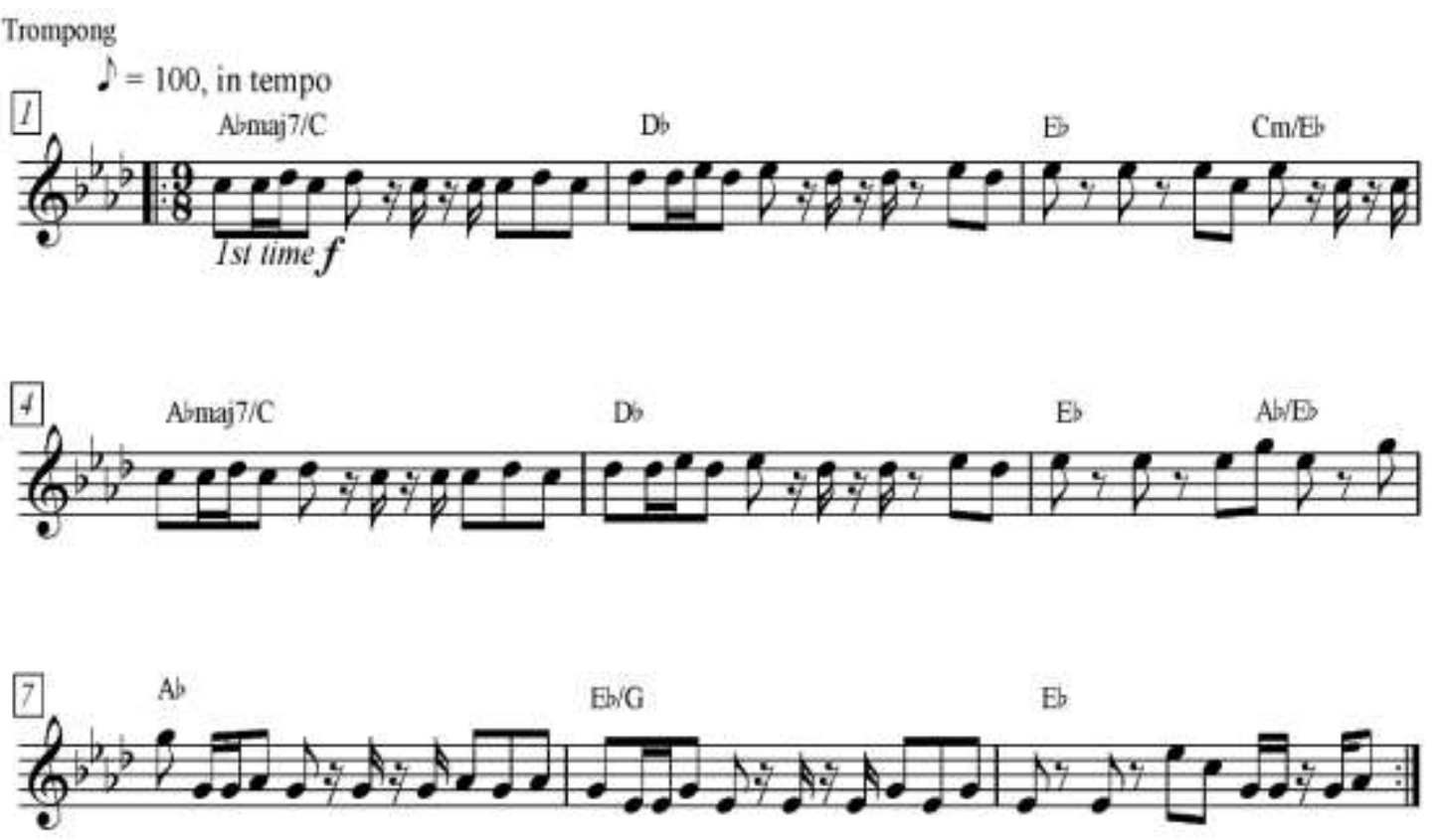

Figure 13

"Trompong" game pattern part A

Figure 13 shows that the trompong game in this section acts as the accompaniment melody of the main melody that is played with the trumpet. Although it acts as an accompaniment melody, the trompong melody in this section has a different motive from the main melody, as if the trompong melody does not follow and accompany the main melody. After explaining the trompong game, it is followed by the jegogan pattern which can be seen in Figure 14.

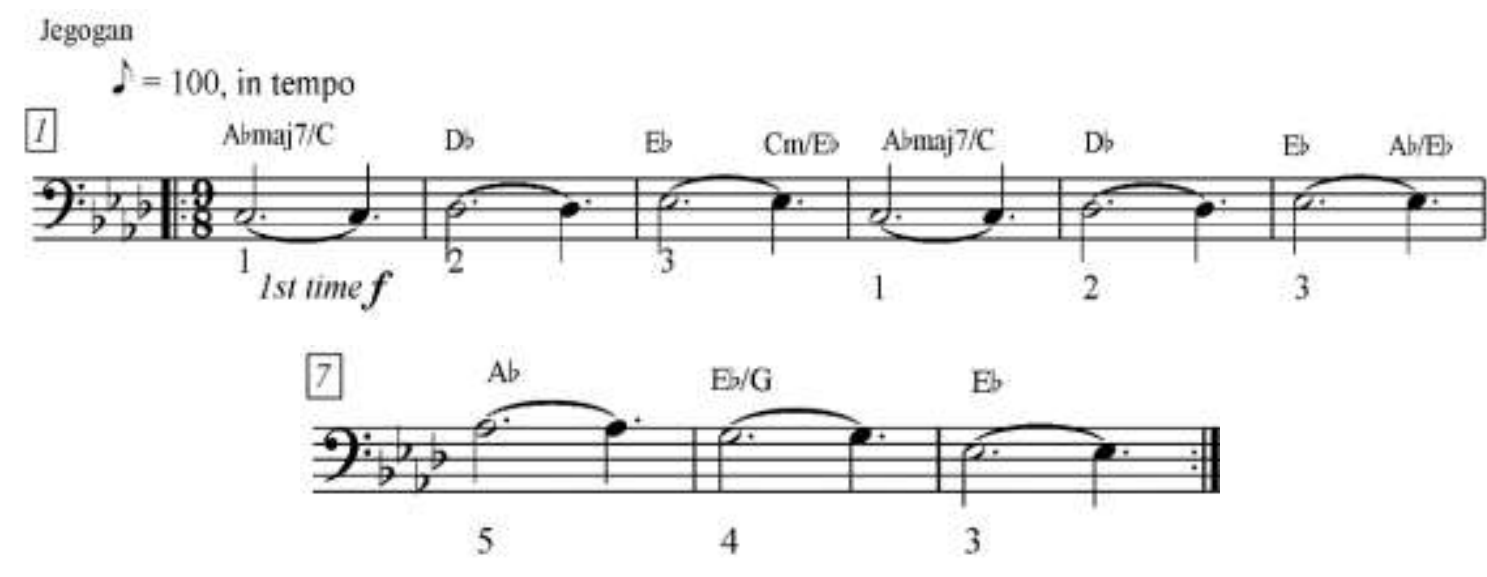

Figure 14

Jegogan game patterns part A

(Source: Agus Cahyadi, 2018). 
From Figure 14 it can be concluded that, the game of jegogan in this section is to emphasize the progress chord, and act as accompanist. Jegogan is always on the first beat in every bar. After an explanation of part $A$, it is proceeded with an explanation of part B.

\section{Part B}

Part $B$ is a period that has two phrases namely question phrase (antecedent) and answer phrase (consequent). A period is a number of bar rooms (usually 8 or 16 bars) that constitute a unity. For sentences/periods, uppercase letters are generally used ( $A, B, C$, etc.). If a sentence/period is repeated with changes, the capital letters are accompanied by an accent (') such as A B A' (Prier SJ, 1996: 2). The progress chord used in this section can be seen in Figure 15.

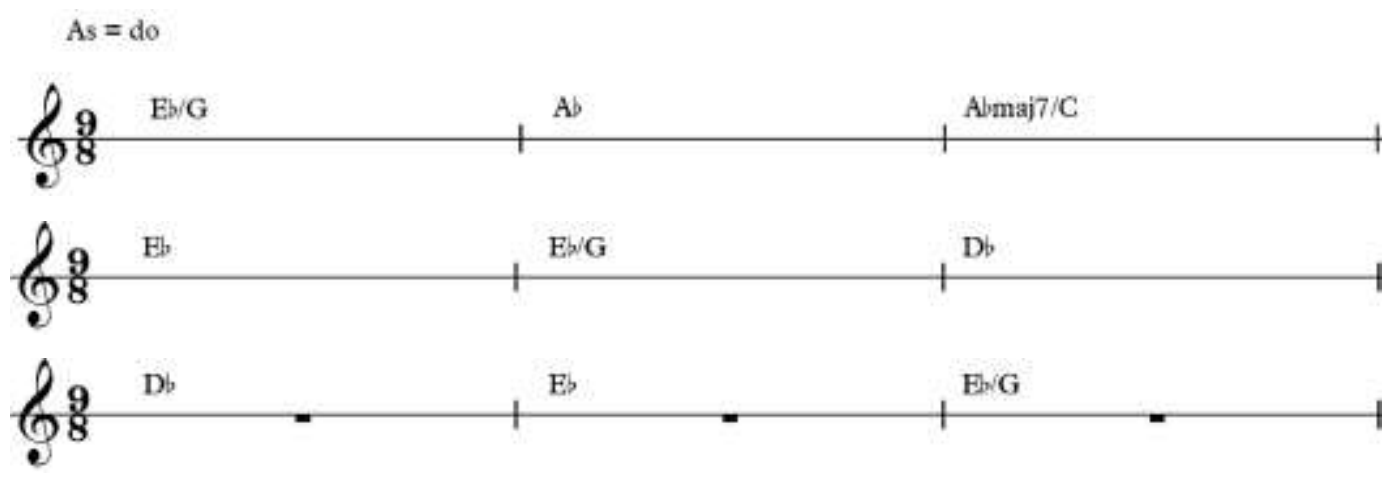

Figure 15

Progress chord part B

(Source: Agus Cahyadi, 2018).

Figure 15 shows that this part consists of 4 chords, where in one bar there is one chord with a count of 3 taps. The tempo used in this section is allegro (100MM) which is a fast and happy tempo. In this section there is a starting mark of four moles which means that this section has a basic tone $A s=$ do. The dynamics used are mezzoforte (mf) which is a half-hard dynamics, then the harder (cressendo) starts at the initial beat of the first time bar of part $B$ to the fortessimo (ff) which is a very hard dynamic. The description of the period part B, dynamics, question phrases (antecedents) and answer phrases (consequent) can be seen in Figure 16. 


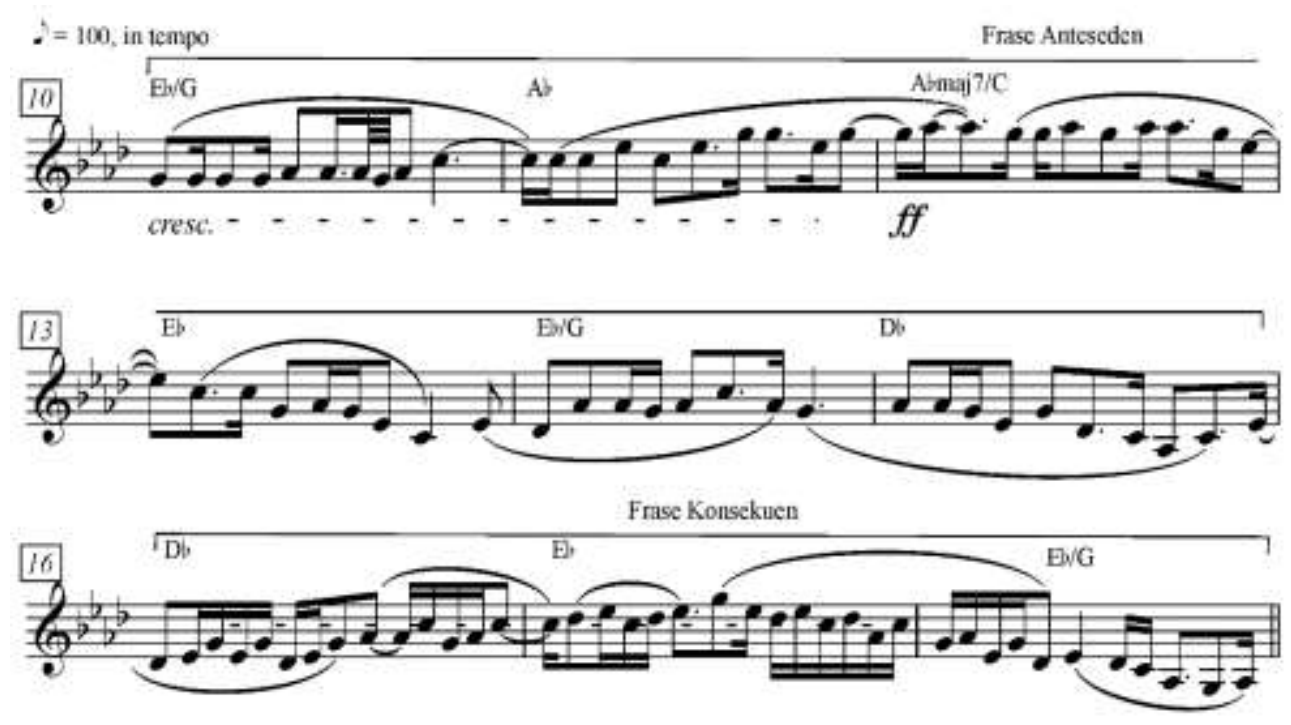

Figure 16

Period part B

(Source: Agus Cahyadi, 2018).

The description of figure 16 states that, this part consists of 9 bars starting from 10 bars at the beginning of the beat until 18 at the end of the beat. This section consists of two phrases, namely the question phrase (antecedent) and the answer phrase (consequent).

The initial antecedent phrase or number of bars (usually $1-4$ or $1-8$ ) is called a question sentence or front sentence, because it usually stops with a floating tone. It can be said generally with a "comma" here; there is a dominant chord. The impression is not finished. It is expected that the music will continue (Prier SJ, 1996: 2). The antecedent phrase in this section starts from the first 10 beat time to 15 at the final beat. The description of the antecedent phrase can be seen in Figure 17.

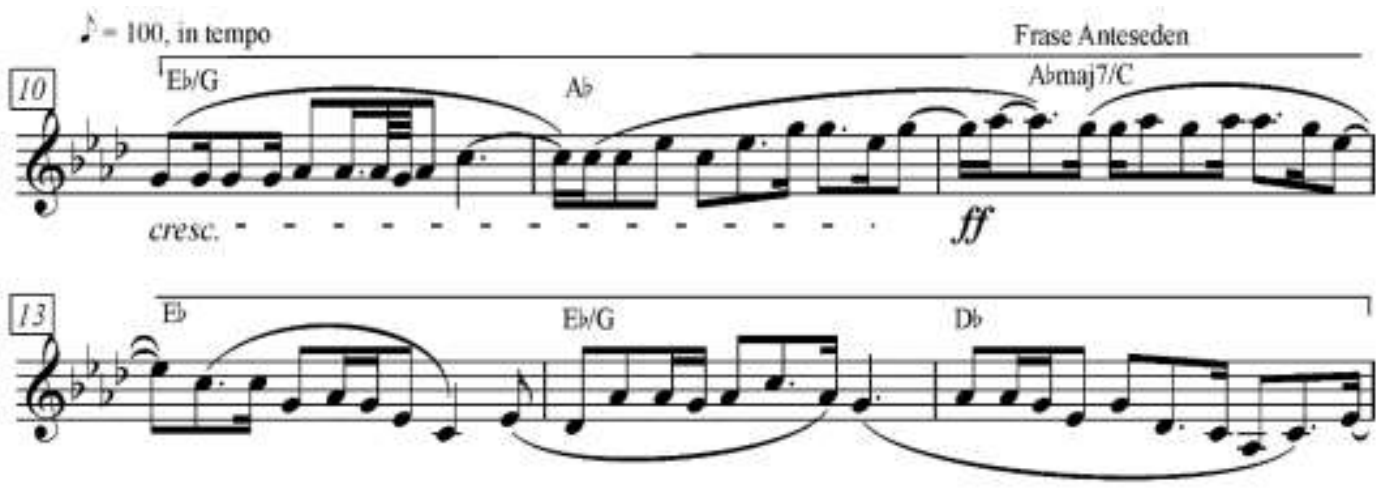

Figure 17

The antecedent phrase part $B$

(Source: Agus Cahyadi, 2018). 
From Figure 17 it can be concluded that, in this question phrase consists of six bars. There is no motive in this section. There is a cressendo dynamic which means getting louder, starting from the 10th beat of the first beat until the 12th beat of the first beat reaches the fortessimo dynamics (ff) which means very loud which is then followed by the consistent phrase part B.

The consequent phrase in this section starts from the 16th bar at the start of the beat to the 18th bar at the end of the beat. Similar to the antecedent phrase in this section, the consequent phrase in this section also does not have a semi-phrase because of the short duration and composition which has a form which deviates from the rules. According to Prier SJ (1996: 19), every exception to the general rules must be supported by a reasonable reason, which adds to the beauty. The consequent phrases in part B can be seen in Figure 18.

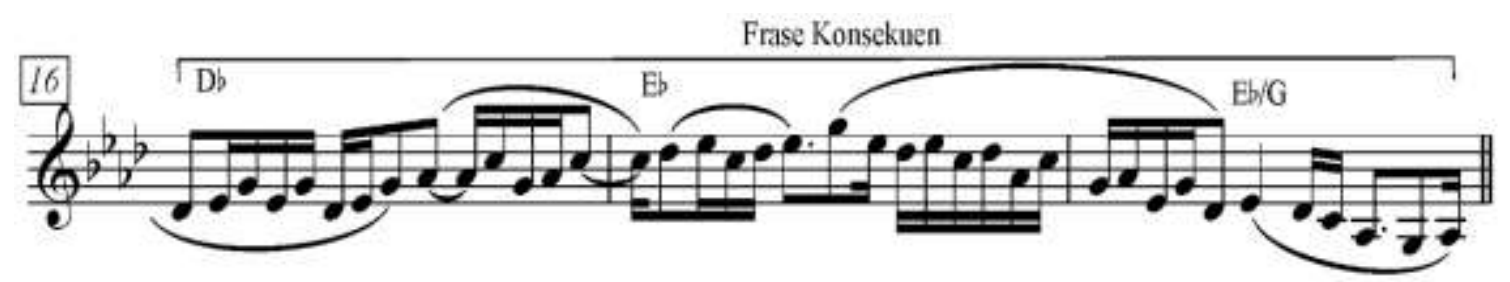

Figure 18

The consequent phrase part $B$

(Source: Agus Cahyadi, 2018).

The description of figure 18 shows that the consequent phrase consists of three bars; there is no motive in this section. The instruments used in this section are trumpet, trombone, trompong, and jegogan. The trombone play pattern can be seen in Figure 19.
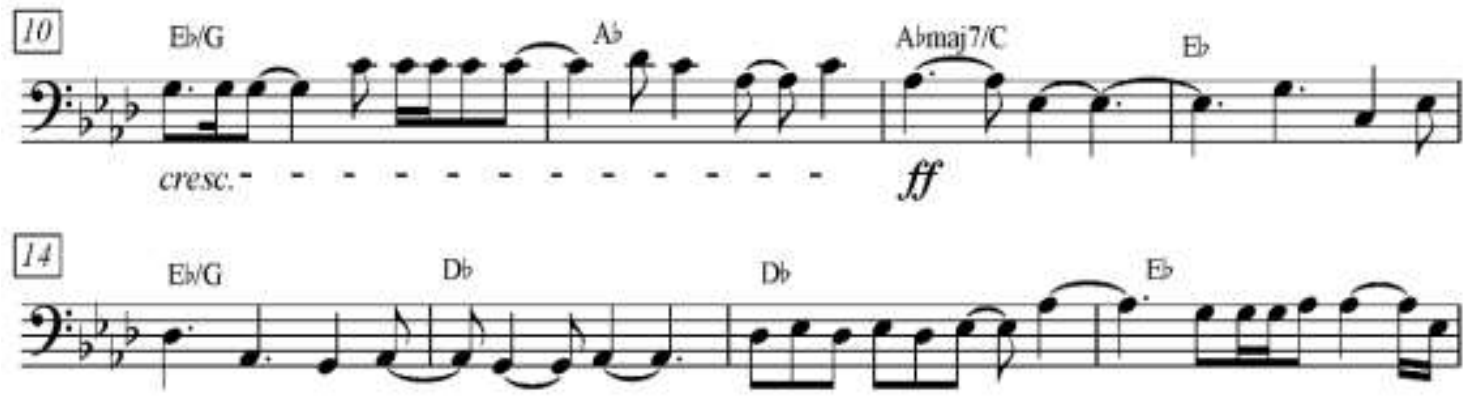


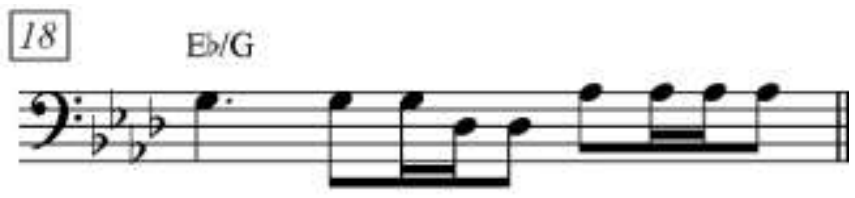

Figure 19.

Trombone game pattern part B (Source: Agus Cahyadi, 2018).

From the description of Figure 19 it can be concluded that the trombone in this section acts as the accompaniment of the principal melody played by the trumpet. The trombone in this section also acts as a chord progress marker. Trombone in this section plays a different pattern than the trumpet and plays the melody on its own without having to match the main melody of the trumpet. This is then continued with the part B trumpet play pattern seen in Figure 20.
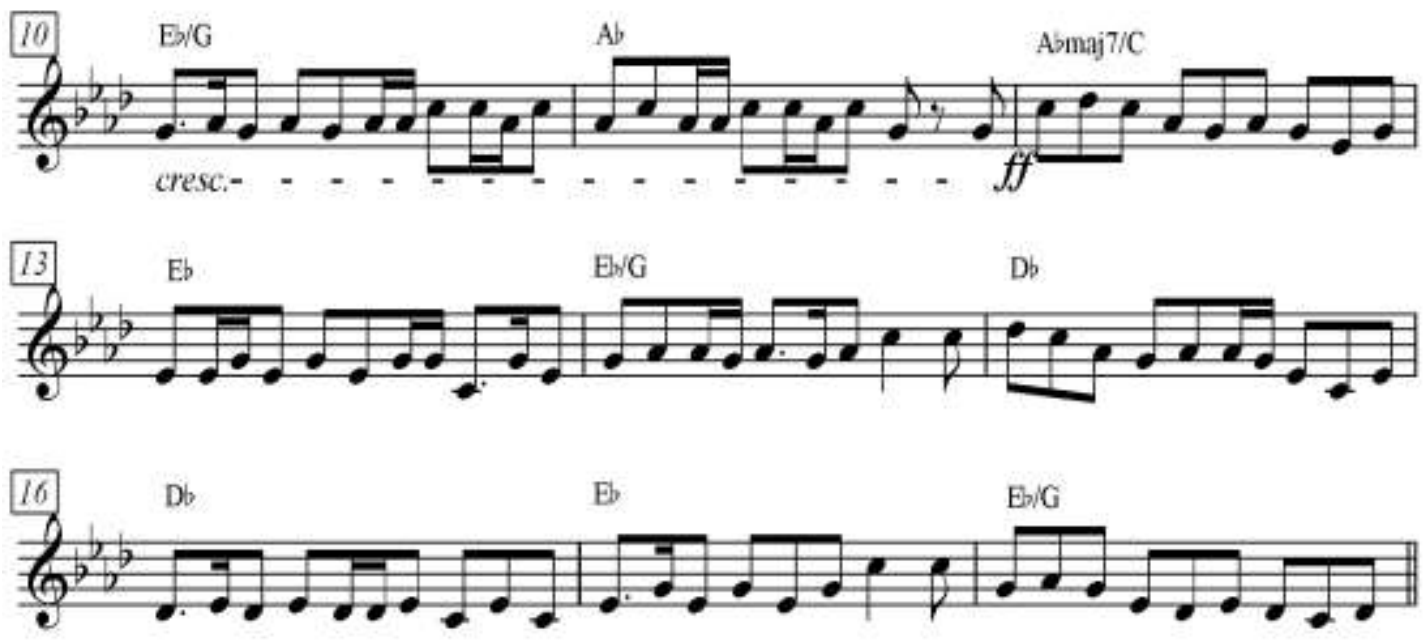

Figure 20.

Trompong game pattern part $\mathrm{B}$

(Source: Agus Cahyadi, 2018).

Figure 20 shows that the trompong game in this section acts as the accompaniment melody of the main melody played with the trumpet. Although it acts as a accompaniment melody, the trompong melody in this section has a different motive from the main melody, as if the melody in this trompong does not follow and accompany the main melody. After explaining the trompong game, it is proceeded with the jegogan pattern which can be seen in Figure 21. 


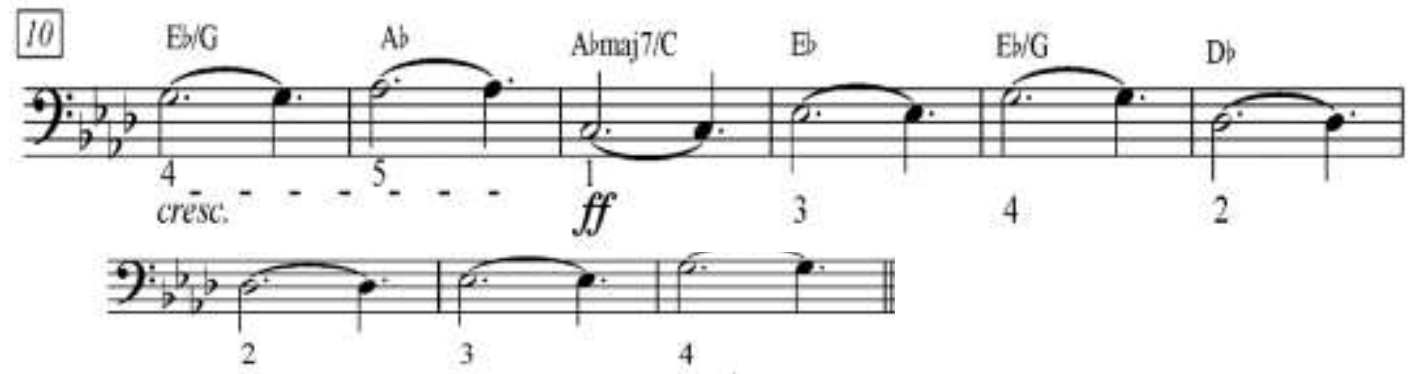

Figure 21.

Jegogan game pattern part $B$

(Source: Agus Cahyadi, 2018).

From Figure 21, it can be concluded that the game of jegogan in this section is to emphasize the progress of the chord, and to act as a companion. Jegogan is always on the first beat in every bar. After the explanation about part $B$, the part $C$ will be continued.

\section{Section C}

Part $\mathrm{C}$ of this composition is only a small transition from part $\mathrm{B}$ back again to part $A$. This transition is played trompong solo for 16 beats before entering again into part $A$. There is no sukuk in this part, like the introductory part played solo and free with trompong, as well as part $\mathrm{C}$ is played solo with trompong and is played freely because it does not use sukat and adjusts the dynamics played in part $\mathrm{B}$. there is a starting mark of four moles which means that this part is played in the basic tone As $=$ do. Only the trompong solos are played, so there are no phrases in this section. The parts of the trompong game pattern in this section can be seen in Figure 22.

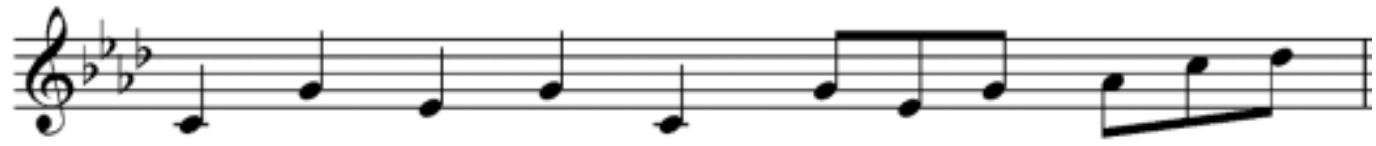

Figure 22.

Trompong game pattern part C

(Source: Agus Cahyadi, 2018).

The decomposition of Figure 22 shows that, this composition has a sukuk 9/8 which means that in one bar consists of nine beats, and there is a starting mark of four moles which shows the basic tone in this composition, namely As = do. The 
tempo used in this composition is allegro which means fast and happy tempo. TromTrom-Trum is instrumental music, and when viewed from the shape and structure of the melody is a three-part song form namely A, B, C.

Windha said that this composition has a 9/8 sukat which is not commonly used in Balinese gamelan compositions, and the tempo that is stable from the beginning to the end of the composition is in stark contrast to the composition of the kebyar gong which tends to have a fluctuating tempo. Judging from the shape of this composition has the form $A A B C A A B$ is very different from the composition of the Balinese gamelan which only has the $A B C$ form. Part $A$ of the Balinese gamelan composition means the head of the composition or in Bali is called kawitan. While part $\mathrm{B}$ in the composition of Balinese gamelan is called a comedian which means the body or the main part of a song from the composition (Bandem, 2013: 150). Part $C$ of the Balinese composition is the part of the foot or commonly called Pengecet or Pekaad in the composition of Balinese gamelan.

Connected with the form of Balinese gamelan composition, this composition is divided into three parts, namely in the kawitan section is the introduction that is played solo with trompong and played freely without sukat. The melody lasts for 43 beats, with the jegogan tone at the end, where the trumpet enters with the jegogan, and with the same tone. In this section the trompong player has the freedom to improvise with playing techniques and with tempo. It starts with a fast tempo and enters the 18th beat and starts to slow down and reaches normal when the other instruments start simultaneously. The tempo slows down and finally reaches the normal tempo.

At the introduction there is a starting mark of four moles which means that the basic note in this introduction is played with the basic tone As = do. The dynamics used in this section are forte $(f)$ which is a hard dynamic. Then in the crew section is divided into two parts, namely part $\mathrm{A}$ and part $\mathrm{B}$.

Part A starts from time 1 to time 10 with different dynamics. The first part $A$ uses forte dynamics (f) which are hard dynamics, and in the second part $A$ uses mezzo-forte (mf) dynamics which are rather hard dynamics. Every bar in this composition is always jegogan in the first beat, but jegogan does not always play the same melody as the main melody, in bars 1,4 , and 7 the jegogan does not play the 
same melody as the main melody, this is not common in Balinese gamelan compositions. the jegogan always plays the same melody as the main melody.

Part $B$ starts from time 10 to time 18. Same as in part $A$, in this section there is also the jegogan as a barring barrier and is always played at the beginning of the bar in the first beat, the jegogan in this section does not always play the same melody as the main melody, except in the bars 10,13, 16 the jegogan plays the same melody as the main melody. In part B uses mezzo-forte (mf) dynamics which are rather hard dynamics, then cressendo or harder to reach fortessimo dynamics (ff) which is very hard dynamics.

Part $\mathrm{C}$ in this composition cannot be said to be a painter because in this part it only functions as a transition from part B back to part $A$, and in part $C$ only a trompong solo is played along the 16 beats and ends with the entry of jegogan on the final beat. So the form of this composition is AABCAAB.

\section{CONCLUSION}

Trom-Trom-Trum which means trompong, trombone, and trumpet uses four instruments consisting of two Western instruments namely trombone and trumpet, and two Balinese gamelan instruments namely trompong and one pair of jegogan whose function in this composition as accents.

Trom-Trom-Trum uses the concept of three main instruments that begin with the letter "t" and three are numbers that are often used in the life of the HinduBalinese community. The instruments used in Trom-Trom-Trum consist of four instruments, namely a trumpet that functions as the main melody of the song, then trompong, trombone, and jegogan which act as accompanists. Trom-Trom-Trum uses a starting mark of four moles which means that this composition is played with the basic tone As = do, with an allegro tempo (100MM) which means fast and happy, using a 9/8 sukat, which means that in one bar there is nine beats. This composition has a duration of 5:14 minutes, is a form of instrumental music composition, when viewed from the shape and structure of the melody, this composition is in the form of three parts, namely AABCAAB. This composition is an example of a composition that deviates from the rules of music science.

The structure in Trom-Trom-Trum starts from the introduction that uses the dynamics of forte $(f)$, is played solo with trompong and does not use sukat because 
in this section the trompong player uses taste. This is followed by the structure of part A.

Part $A$ is a period consisting of two phrases, namely the question phrase (antecedent) and the answer phrase (consequent), which uses the dynamics of forte (f) which is a hard dynamic. This section consists of 9 bars, which begin with 1 at the beginning of the beat until 9 at the end of the beat and there are two semi-phrases in the antecedent phrase and no semi-phrases in the consequent phrases. The tempo used in this section, namely allegro (100MM) which is a fast and happy tempo, and there is a starting mark of four moles which means that this section is played with the basic tone $A s=$ do. This section is repeated again, but with a different dynamic in the second part. The second part A uses mezzo-forte dynamics which are rather hard dynamics which then proceed with the structure contained in part $B$.

Part $B$ is a period that has two phrases, namely the antecedent phrase and the consequent phrase. The tempo used in this section is allegro (100MM) which is a fast and happy tempo. Then there is the beginning mark of four moles which means that this part has the basic tone As = do. The dynamics used are mezzo-forte (mf) which is a half-hard dynamics, then the harder (cressendo) starts at the initial beat of the first time bar of part $B$ to the fortessimo (ff) which is very hard dynamics. This is followed by the structure in section $\mathrm{C}$.

Part $\mathrm{C}$ in this composition is only a small transition from part $\mathrm{B}$ back again to part $A$. This transition is played with trompong solo for 16 beats before entering again into part $A$. There is no sukuk in this part, like the introduction part played solo with trompong in a manner free, so also part $\mathrm{C}$ is played solo with trompong and played freely because it does not use sukat and adjusts the dynamics played in part $B$. There is a starting mark of four moles which means that this part is played in the basic tone As = do. Only the trompong solos are played so there are no phrases in this section.

By having a three-part form, this composition is an art that generally functions as entertainment.

\section{REFERENCES}

Andjani, Karina. 2014. Apa itu Musik? Jakarta: Penerbit Universitas Indonesia. 
Ariesta, I Made Jacky; Ardini, Ni Wayan; Darmayuda, I Komang; Sumerjana, Ketut. 2018. "Analisis Bentuk dan Struktur Komposisi 'Morning Happiness' Gus Teja", Journal of Music Science, Technology, and Industry, Vol. 1, No. 1, October, http://jurnal.isi-dps.ac.id/index.php/jomsti/article/view/504. Date accessed: 15 May 2019.

Bandem, I Made. 2013. Gamelan Bali di Atas Panggung Sejarah. Denpasar: Badan Penerbit STIKOM Bali.

Banoe, Pono. 2003. Kamus Musik. Yogyakarta: Kanisius.

Djohan. 2005. Psikologi Musik (Second Edition). Yogyakarta: Best Publisher Yogyakarta.

Jamalus. 1988. Panduan Pengajaran Buku Pengajaran Musik melalui Pengalaman Musik. Jakarta: Proyek Pengembangan Lembaga Pendidikan Jakarta.

Kamien, Roger. 1998. Music an Appreciation, Fourth Edition. New York: McGraw Hill Book Company.

Mahardika, Komang Wira Adhi. 2018. “Lantunan Masa Kecil dalam 'Lullabybianu’”, Journal of Music Science, Technology, and Industry, Vol. 1, No. 1, October, http://jurnal.isi-dps.ac.id/index.php/jomsti/article/view/26. Date accessed: 5 May 2019.

Prier SJ, Karl-Edmund. 1996. IImu Harmoni. Yogyakarta: Pusat Musik Liturgi.

Prier SJ, Karl-Edmund. 1996. IImu Bentuk Musik. Yogyakarta: Pusat Musik Liturgi. 